\title{
Research on Synchronous Construction Control Technology for the Pylon and Girder of Maling River Cable-stayed Bridge
}

\section{Shao-Hui XIONG ${ }^{1, a,{ }^{*},}$ You-Jin ZHANG ${ }^{1, b}$}

${ }^{1}$ China Merchants Chongqing Communications Technology Research \& Design Institute Co., Ltd., China

axiongshaohui@cmhk.com, bzhangyoujin@cmhk.com

${ }^{*}$ Corresponding author

Keywords: Cable-stayed Bridge, Synchronous Construction, Contrast Research, Feasibility, Construction Control.

\begin{abstract}
Pier No. 8 of Maling River Bridge was constructed by synchronous construction method of pylon and girder, while pier No. 9 was constructed by conventional construction method. In this paper, synchronous construction feasibility is analyzed theoretically by construction simulation computation based on the Maling River Bridge, and its construction control technology is stated.
\end{abstract}

\section{Project Profile}

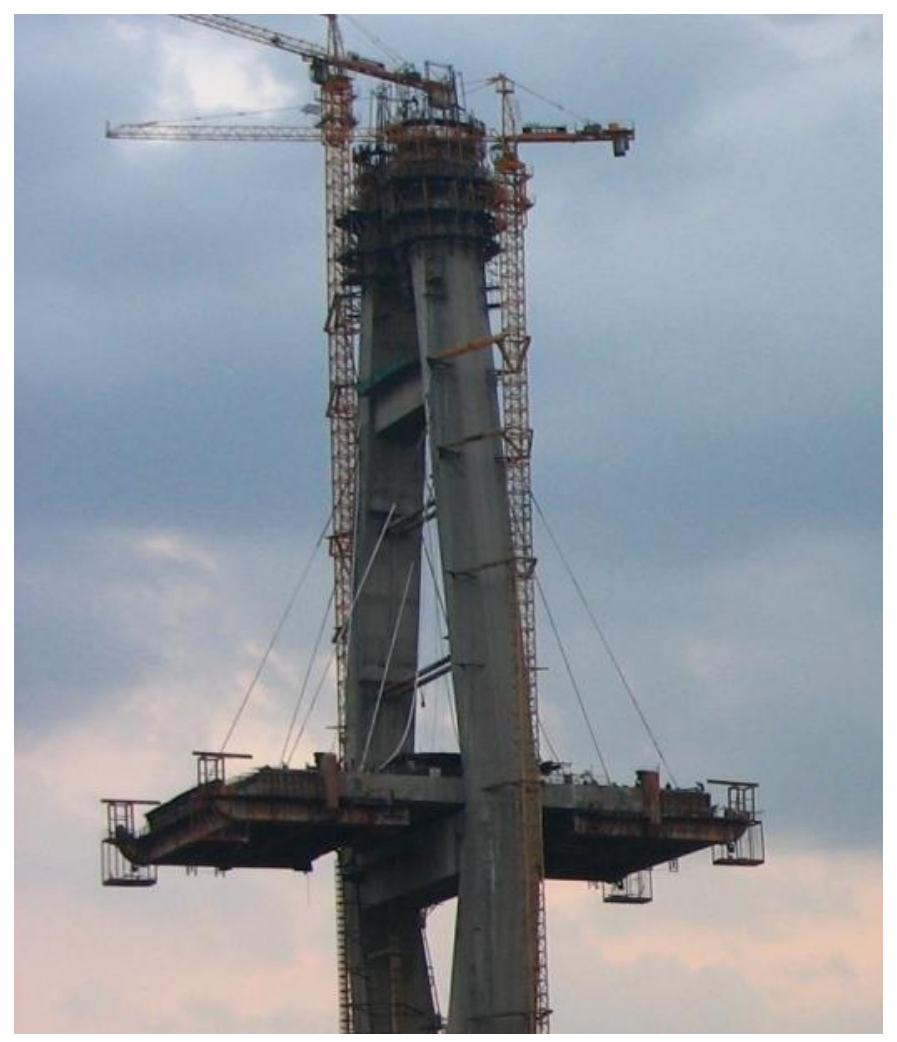

Fig.1 Synchronous Construction of Pylon and Girder

The main bridge of Maling River bridge is a three-span prestressed concrete cable-stayed bridge with double-pylon and double-cable of $155+360+155 \mathrm{~m}$, and a semi-floating system. Its main girder is $\Pi$ type section, and a prestressed system in both horizontal and vertical directions. Its main 
pylon is a gems type structure with two cross tie beams up and down ${ }^{[1]}$. To reduce the 6 months of schedule difference of construction, pier No.8 was constructed by the synchronous construction method during construction of girders No.1-9. Pier No.9 was constructed by the conventional construction method. The construction situations of two sides were shown in Fig.1 and Fig.2 respectively.

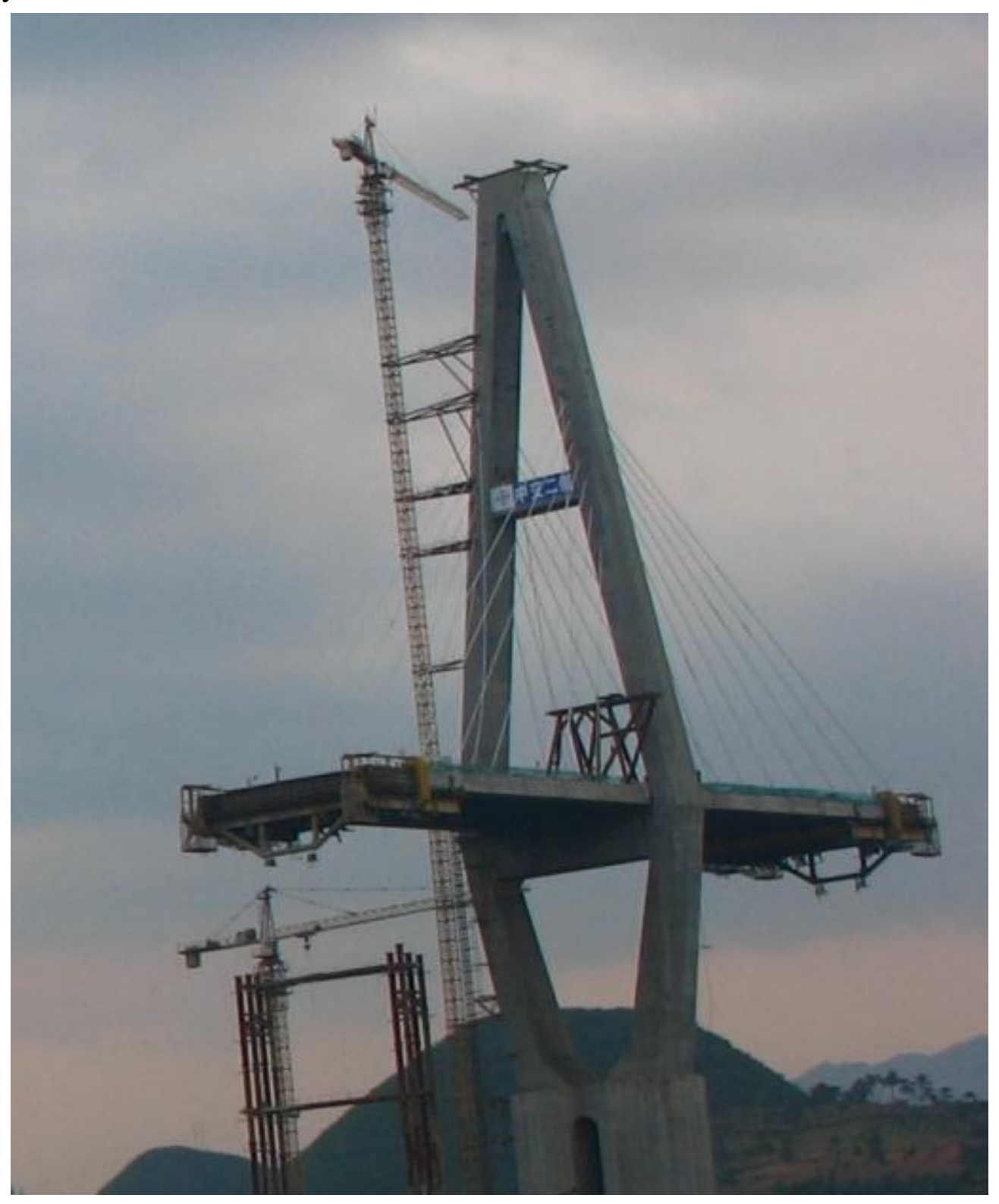

Fig.2 Conventional Construction

\section{Feasibility Analysis}

Cable-stayed bridge is a multiply redundant hyper-static structure composed of pylon, girder and stay cables. In theory, a reasonable construction state could be determined after construction method is determined ensuring a reasonable completed bridge ${ }^{[2,3]}$. These two different construction methods should be done under different reasonable construction states. The emphasis is on the difference between these two reasonable construction states which is the key to the reasonable completed bridge state determined by the designer. Two 3-dimensionalfinite models were built respectively to simulate synchronous construction and conventional construction of tower and beams according to 
the actual construction progress, which are shown in Fig.3 and Fig.4. The results obtained from the two models were compared to analyze the technical feasibility of synchronous construction $\operatorname{method}^{[4]}$.

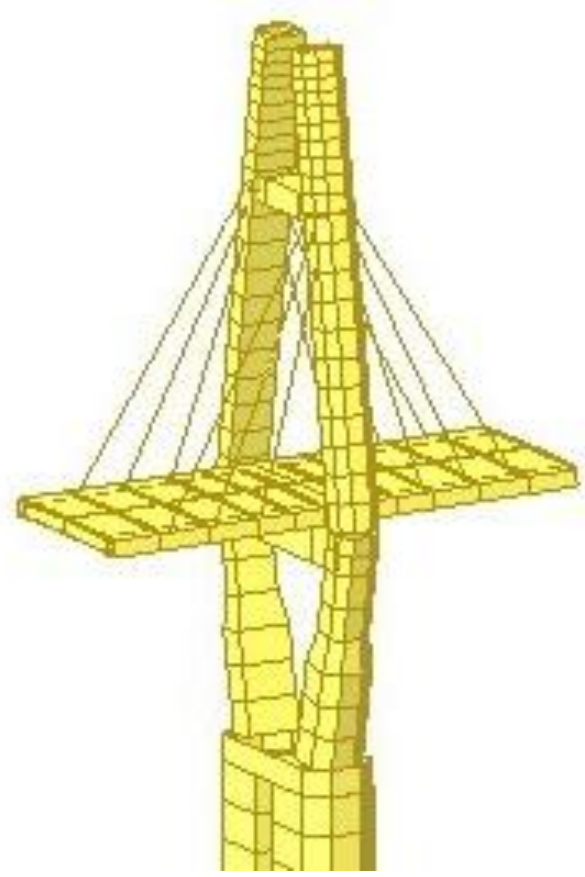

Fig.3 Synchronous Construction Computation Model

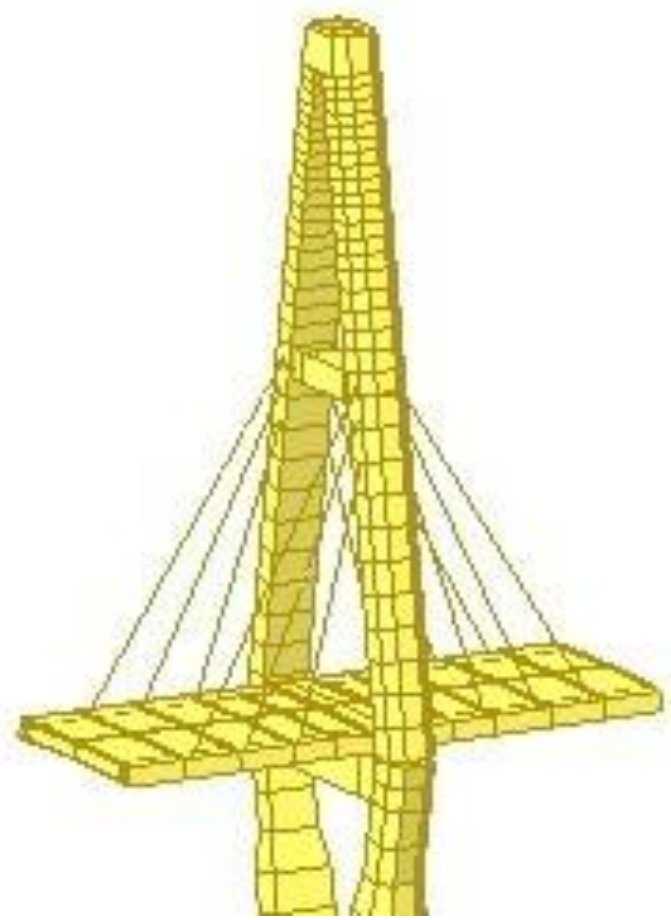

Fig.4 Conventional Construction Computation Model

\section{Cable Force Comparison of Completed Bridge}

Stay cable is the key supporting component of the cable-stayed bridge, and cable force is the key influence factor of the main girder stress. A reasonable cable force of completed bridge is important for achieving a reasonable competed bridge state. In Fig.5, these two methods have little impact on 
the cable force of completed bridge; their maximum impact on the cable force near the main pylon is only $3.3 \mathrm{kN}$ which is less than $0.5 \%$ of the cable force of completed bridge. It is concluded that the synchronous construction method has little impact on the cable force of completed bridge.

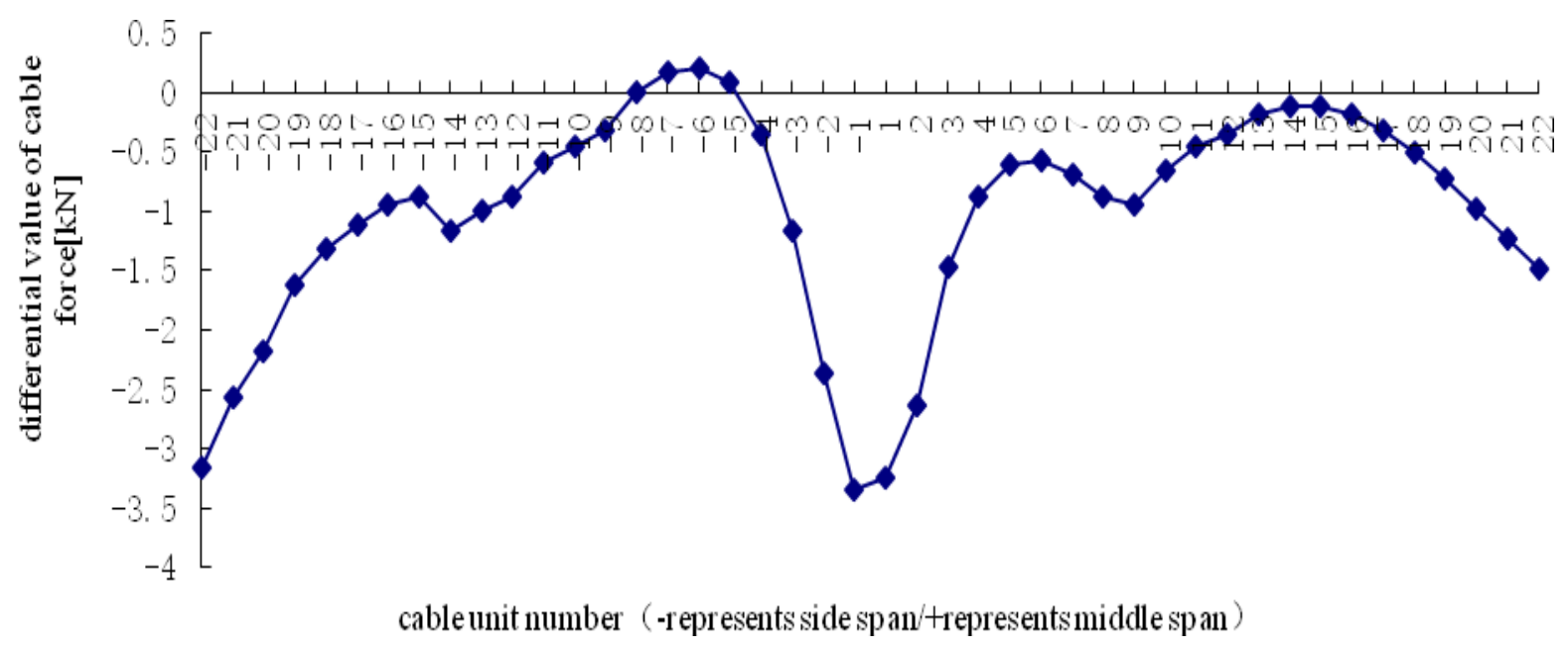

Fig.5 The Differential Value of Cable Force of Completed Bridge under Synchronous Construction and Conventional Construction

\section{Alignment Comparison of Completed Bridge}

Girder alignment is a key factor to weigh completed bridge state. Alignment of a reasonable completed bridge could be achieved by setting up cambers during construction of each segment. It is shown in Fig.6, the difference of the camber values calculated through these two construction methods is within $4 \mathrm{~mm}$. It is concluded that the synchronous construction method has little impact on the alignment of completed bridge.

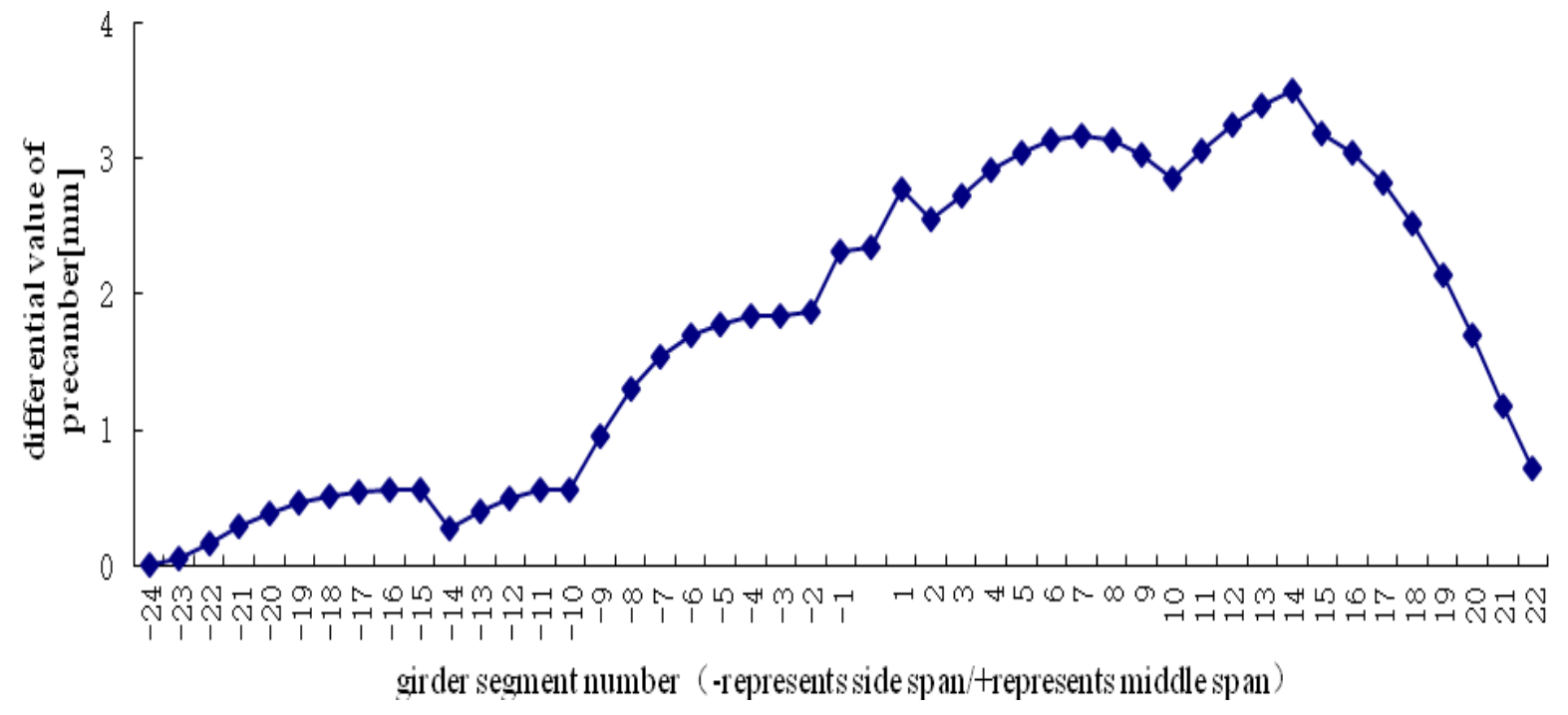

Fig.6 The Differential Value of Camber of Girder Segment under Synchronous Construction and Conventional Construction

\section{Girder Stress Comparison of Completed Bridge}

There is a direct relationship between a reasonable girder stress and the operation state of 
completed bridge. Girder stress is the most important index of a reasonable completed bridge. The differential value of girder stress of completed bridge calculated through these two construction methods is presented in Fig.7. It is shown in Fig.7; stress differences for most of the girder segments are small, less than $0.001 \mathrm{MPa}$.

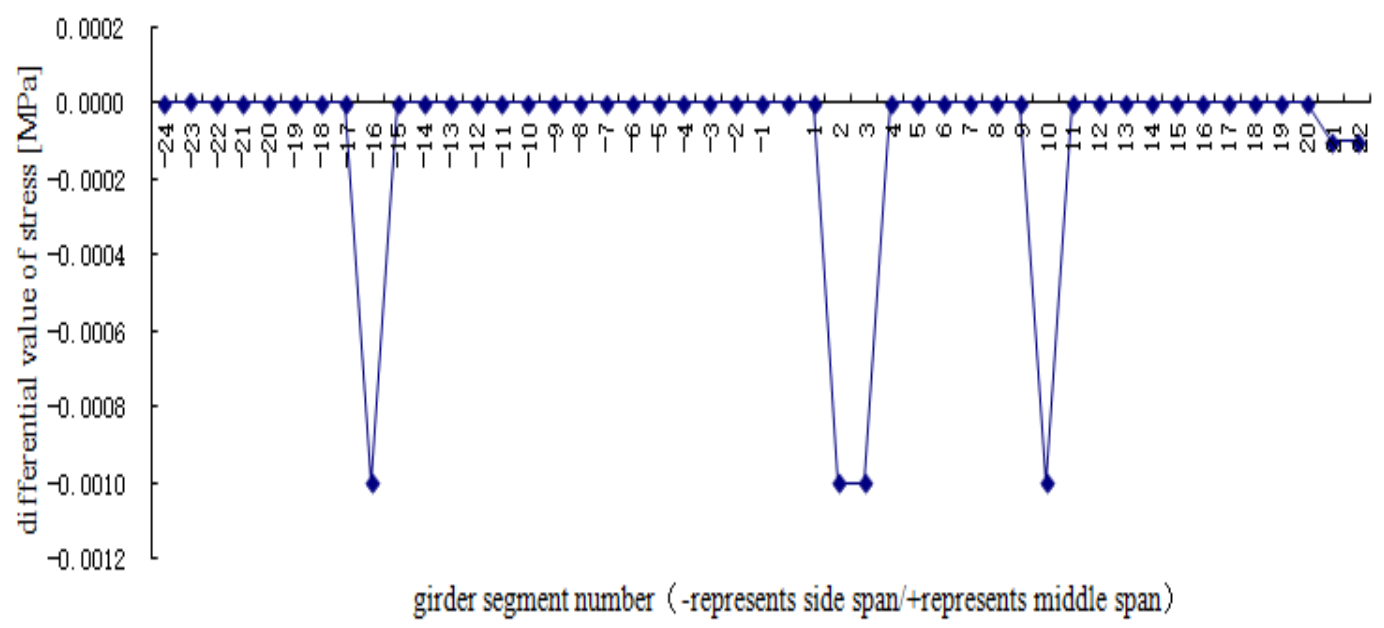

Fig.7 The Differential Value of Whole Bridge Stress of Beam by Tower-beam Synchronization-normal Construction

\section{Stress and Displacement Comparison of Girder}

Cable No.1 and cable No.2 are anchored below the upper cross beam; therefore their cable force has small impact on the displacement and stress of pylon support. The cable forces in the vertical direction, axial direction and transverse direction have a large impact on the section stress of the pylon support bottom and the displacements in the axial direction and transverse direction, even causing buckling failure, before these two pylon supports are linked or sealing. In Fig.1, the simulation values of the section and displacements in the axial direction and transverse direction calculated by these two construction methods are presented in Table 1 .

Stress Comparison of Pylon Support Bottom Sections. Cables No.3-No.9 are anchored above the upper cross beam, the cable tension will have an important effect on the section stress on the bottom of the pylon support. Small compressive stress reserve under the synchronous construction will affect the stress safety of this section. The simulation calculation result under the synchronous construction shows the minimum compressive stress is $0.2 \mathrm{MPa}$, tensile stress is absent. The minimum stress under the conventional construction is $1.21 \mathrm{MPa}$.

Axial Displacement Comparison of Pylon Supports. Asymmetric tension of the cable force of the middle and side spans will affect the displacements in the axial direction of their pylon supports. The calculation result of the synchronous construction simulation shows the maximum axial displacement occurs after tensioning of cable No.9, which is $4.8 \mathrm{~mm}$, while the maximum axial displacement under the conventional method is $2.5 \mathrm{~mm}$. The difference between the calculation results of these two models is small.

Transverse Displacement Comparison of Pylon Support. Transverse cable forces of side span and middle span cause transverse displacement of the pylon supports. The calculation result of the 
synchronous construction simulation shows the maximum transverse displacement occurs after tensioning of cable No.9, which is $26 \mathrm{~mm}$, while the maximum transverse displacement under the conventional method is $2.2 \mathrm{~mm}$. So the transverse connection between these two pylon supports should be strengthened to prevent large displacement or even buckling failure in the transverse direction of the pylon supports.

Tab.1 Simulation Values of the Section Stress on the Bottom of the Pylon Support and the Axial Displacement and Transverse Displacement on the Top of the Pylon Support in These Two Construction Methods

\begin{tabular}{|c|c|c|c|c|c|c|}
\hline \multirow{2}{*}{$\begin{array}{l}\text { Working } \\
\text { condition }\end{array}$} & \multicolumn{2}{|c|}{$\begin{array}{l}\text { Section stress on the bottom } \\
\text { of pylon support[MPa] }\end{array}$} & \multicolumn{2}{|c|}{$\begin{array}{l}\text { Axial displacement on the } \\
\text { top of the pylon support[mm] }\end{array}$} & \multicolumn{2}{|c|}{$\begin{array}{l}\text { Transverse displacement on } \\
\text { the top of the pylon } \\
\text { support[mm] }\end{array}$} \\
\hline & $\begin{array}{l}\text { Synchronous } \\
\text { construction }\end{array}$ & $\begin{array}{l}\text { Convention } \\
\text { al } \\
\text { construction }\end{array}$ & $\begin{array}{l}\text { Synchronous } \\
\text { construction }\end{array}$ & $\begin{array}{l}\text { Convention } \\
\text { al } \\
\text { construction }\end{array}$ & $\begin{array}{l}\text { Synchronous } \\
\text { construction }\end{array}$ & $\begin{array}{c}\text { Convention } \\
\text { al } \\
\text { construction }\end{array}$ \\
\hline $\begin{array}{c}\text { After } \\
\text { third } \\
\text { tension } \\
\text { of cable } \\
3 \# \\
\end{array}$ & 0.18 & 1.21 & 0.3 & 0.3 & 2 & 1.3 \\
\hline $\begin{array}{c}\text { After } \\
\text { third } \\
\text { tension } \\
\text { of cable } \\
4 \#\end{array}$ & 0.20 & 1.43 & 0.3 & 1.0 & 4 & 1.4 \\
\hline $\begin{array}{c}\text { After } \\
\text { third } \\
\text { tension } \\
\text { of cable } \\
5 \# \\
\end{array}$ & 0.24 & 1.65 & 0.5 & 1.2 & 7 & 1.6 \\
\hline $\begin{array}{c}\text { After } \\
\text { third } \\
\text { tension } \\
\text { of cable } \\
6 \#\end{array}$ & 0.29 & 1.94 & 1.0 & 0.7 & 10 & 1.7 \\
\hline $\begin{array}{c}\text { After } \\
\text { third } \\
\text { tension } \\
\text { of cable } \\
7 \#\end{array}$ & 0.33 & 2.13 & 2.0 & 0.3 & 14 & 1.9 \\
\hline $\begin{array}{c}\text { After } \\
\text { third } \\
\text { tension } \\
\text { of cable } \\
8 \# \\
\end{array}$ & 0.38 & 2.47 & 3.6 & 2.5 & 20 & 2.0 \\
\hline $\begin{array}{c}\text { After } \\
\text { third } \\
\text { tension } \\
\text { of cable } \\
9 \#\end{array}$ & 0.45 & 2.69 & 4.8 & 3.1 & 26 & 2.2 \\
\hline
\end{tabular}

Note: The displacement data under the conventional construction is the unit displacement data at the same elevation on the top of the pylon support under this working condition in the synchronous construction method. 


\section{Control of Pylon and Girder Synchronous Construction ${ }^{[5]}$}

From the above, the synchronous construction could achieve a reasonable completed bridge state with relevant technical assurance. The simulation calculation was done under reasonable working conditions, so the results were also ideal. In practice, there are errors of cable tensioning, girder weight, prestressed tensioning, etc. So the primary working content includes girder alignment control, cable force control, girder stress monitoring, pylon support stress and displacement monitoring.

\section{Girder Alignment Control}

During girder alignment control, pre-camber and the cable force of the third tensioning of the stay cable is adjusted to control the elevation of present segment. Girder elevation of the third tensioning is adopted when the stay cable directly acts on the girder. The third tensioning should be completed when the temperature is very stable to abolish the effect of temperature on the elevation and cable force. The test values and theoretical values of elevation after the third tensioning of the segments of girders No.1-No.9 of the middle span and side span are listed in Table 2. It is seen in the table that the maximum elevation error is $18 \mathrm{~mm}$, which satisfies construction accuracy requirements.

\section{Cable Force Control}

During construction of each girder segment, cable force should monitor completely. During the first two tensioning of the stay cable which acts on the basket, elevation control is the key task; cable force accuracy could be ignored with error less than $10 \%$. During the third tensioning which acts on the girder, elevation and cable force should be controlled at the same time. The cable force error should be controlled within 5\%. The test values and theoretical values of elevation after the third tensioning of the segments of girders No.1-No.9 of the middle span and side span are listed in Table 2. It is seen in the table that the accuracy of the cable force is controlled with the error less than $5 \%$.

Elevations on the bottom of the girder are listed in the table. The theoretical values are calculated through the computation model of the monitoring company, the same below.

\section{Girder Stress Monitoring}

During construction, the stress of the key girder section should be monitored. During test, each working condition was tested for two times to deduct the sensor reading difference of two working conditions and to abolish the effect of concrete shrinkage and creep and stress sensor floatation, which ensures the reliability of the stress test value. For this bridge, there are 9 stress monitoring sections of the girder, and there are 11 stress sensors for each section. Fig. 8 shows test points layout of the girder stress. 
Tab.2 The Elevation and the Value of Cable Force after Tensioning of the Segments of the Stay Cables No.1-9

\begin{tabular}{|c|c|c|c|c|c|c|c|c|}
\hline \multirow{2}{*}{$\begin{array}{l}\text { Working } \\
\text { condition }\end{array}$} & \multicolumn{2}{|c|}{$\begin{array}{l}\text { Side span elevation } \\
{[\mathrm{m}]}\end{array}$} & \multicolumn{2}{|c|}{$\begin{array}{l}\text { Middle span } \\
\text { elevation }[\mathrm{m}]\end{array}$} & \multicolumn{2}{|c|}{$\begin{array}{l}\text { Side span cable } \\
\text { force }[\mathrm{kN}]\end{array}$} & \multicolumn{2}{|c|}{$\begin{array}{l}\text { Middle span cable } \\
\text { force }[\mathrm{kN}]\end{array}$} \\
\hline & $\begin{array}{c}\text { Test } \\
\text { elevatio } \\
n\end{array}$ & $\begin{array}{l}\text { Theoreti } \\
\text { cal } \\
\text { elevation }\end{array}$ & $\begin{array}{c}\text { Test } \\
\text { elevatio } \\
n\end{array}$ & $\begin{array}{l}\text { Theoreti } \\
\text { cal } \\
\text { elevation }\end{array}$ & $\begin{array}{c}\text { Test } \\
\text { cable } \\
\text { force }\end{array}$ & $\begin{array}{c}\text { Theoretic } \\
\text { al cable } \\
\text { force }\end{array}$ & $\begin{array}{c}\text { Test } \\
\text { cable } \\
\text { force }\end{array}$ & $\begin{array}{c}\text { Theoretic } \\
\text { al cable } \\
\text { force }\end{array}$ \\
\hline $\begin{array}{l}\text { After third } \\
\text { tension of } \\
\text { cable 1\# }\end{array}$ & $\begin{array}{c}1165.84 \\
1\end{array}$ & 1165.838 & $\begin{array}{c}1165.95 \\
0\end{array}$ & 1165.953 & 2490 & 2450 & 2429 & 2450 \\
\hline $\begin{array}{l}\text { After third } \\
\text { tension of } \\
\text { cable 2\# }\end{array}$ & $\begin{array}{c}1165.81 \\
8\end{array}$ & 1165.811 & $\begin{array}{c}1165.98 \\
2\end{array}$ & 1165.994 & 2363 & 2352 & 2346 & 2352 \\
\hline $\begin{array}{l}\text { After third } \\
\text { tension of } \\
\text { cable } 3 \#\end{array}$ & $\begin{array}{c}1165.75 \\
8\end{array}$ & 1165.776 & $\begin{array}{c}1166.03 \\
6\end{array}$ & 1166.031 & 2448 & 2450 & 2479 & 2450 \\
\hline $\begin{array}{l}\text { After third } \\
\text { tension of } \\
\text { cable } 4 \#\end{array}$ & $\begin{array}{c}1165.74 \\
9\end{array}$ & 1165.763 & $\begin{array}{c}1166.06 \\
3\end{array}$ & 1166.064 & 2640 & 2597 & 2573 & 2597 \\
\hline $\begin{array}{l}\text { After third } \\
\text { tension of } \\
\text { cable } 5 \#\end{array}$ & $\begin{array}{c}1165.72 \\
9\end{array}$ & 1165.737 & $\begin{array}{c}1166.11 \\
2\end{array}$ & 1166.115 & 2830 & 2842 & 2866 & 2842 \\
\hline $\begin{array}{l}\text { After third } \\
\text { tension of } \\
\text { cable } 6 \#\end{array}$ & $\begin{array}{c}1165.69 \\
3\end{array}$ & 1165.704 & $\begin{array}{c}1166.15 \\
9\end{array}$ & 1166.169 & 3133 & 3062.5 & 3075 & 3062.5 \\
\hline $\begin{array}{l}\text { After third } \\
\text { tension of } \\
\text { cable } 7 \#\end{array}$ & $\begin{array}{c}1165.68 \\
2\end{array}$ & 1165.683 & $\begin{array}{c}1166.22 \\
4\end{array}$ & 1166.226 & 3297 & 3283 & 3262 & 3283 \\
\hline $\begin{array}{l}\text { After third } \\
\text { tension of } \\
\text { cable } 8 \#\end{array}$ & $\begin{array}{c}1165.63 \\
7\end{array}$ & 1165.647 & $\begin{array}{c}1166.27 \\
9\end{array}$ & 1166.280 & 3618 & 3528 & 3443 & 3430 \\
\hline $\begin{array}{l}\text { After third } \\
\text { tension of } \\
\text { cable 9\# }\end{array}$ & $\begin{array}{c}1165.62 \\
0\end{array}$ & 1165.622 & $\begin{array}{c}1166.33 \\
0\end{array}$ & 1166.322 & 3896 & 3920 & 3654 & 3626 \\
\hline
\end{tabular}


Tab.3 Girder Stress Data after Tensioning of Segment No.1-9 of the Stay Cable

\begin{tabular}{|c|c|c|c|c|c|c|c|c|c|c|}
\hline \multirow[b]{3}{*}{$\begin{array}{c}\text { Working } \\
\text { conditio } \\
n\end{array}$} & \multicolumn{5}{|c|}{ Side span } & \multicolumn{5}{|c|}{ Middle span } \\
\hline & \multicolumn{3}{|c|}{ upper stress[MPa] } & \multicolumn{2}{|c|}{$\begin{array}{c}\text { lower } \\
\text { stress[MPa] }\end{array}$} & \multicolumn{3}{|c|}{ upper stress[MPa] } & \multicolumn{2}{|c|}{$\begin{array}{c}\text { lower } \\
\text { stress[MPa] }\end{array}$} \\
\hline & $\begin{array}{c}\text { Middl } \\
\text { e } \\
\text { Test } \\
\text { value }\end{array}$ & $\begin{array}{c}\text { End } \\
\text { s } \\
\text { Tes } \\
\text { t } \\
\text { val } \\
\text { ue }\end{array}$ & $\begin{array}{c}\text { Theoret } \\
\text { i- cal } \\
\text { value }\end{array}$ & $\begin{array}{c}\text { Test } \\
\text { value }\end{array}$ & $\begin{array}{c}\text { Theore } \\
\text { ti-cal } \\
\text { value }\end{array}$ & $\begin{array}{c}\text { Middl } \\
\text { e } \\
\text { Test } \\
\text { value }\end{array}$ & $\begin{array}{l}\text { End } \\
\text { s } \\
\text { Test } \\
\text { valu } \\
\text { e }\end{array}$ & $\begin{array}{c}\text { Theore } \\
\text { ti-cal } \\
\text { value }\end{array}$ & $\begin{array}{c}\text { Test } \\
\text { value }\end{array}$ & $\begin{array}{c}\text { Theoret } \\
\text { ic-al } \\
\text { value }\end{array}$ \\
\hline $\begin{array}{c}\text { After } \\
\text { third } \\
\text { tension } \\
\text { of cable } \\
2 \#\end{array}$ & 4.07 & 2.38 & 3.26 & -0.53 & -0.01 & 4.12 & 2.41 & 3.27 & -0.49 & -0.01 \\
\hline $\begin{array}{c}\text { After } \\
\text { third } \\
\text { tension } \\
\text { of cable } \\
3 \#\end{array}$ & 4.51 & 3.01 & 3.39 & 0.01 & 0.12 & 4.83 & 2.97 & 3.42 & 0.03 & 0.07 \\
\hline $\begin{array}{c}\text { After } \\
\text { third } \\
\text { tension } \\
\text { of cable } \\
4 \#\end{array}$ & 5.06 & 2.93 & 3.12 & 0.52 & 0.98 & 3.19 & 2.75 & 2.96 & 0.62 & 1.25 \\
\hline $\begin{array}{c}\text { After } \\
\text { third } \\
\text { tension } \\
\text { of cable } \\
5 \#\end{array}$ & 4.49 & 2.15 & 2.98 & 1.07 & 1.73 & 3.02 & 2.17 & 2.83 & 1.01 & 1.96 \\
\hline $\begin{array}{c}\text { After } \\
\text { third } \\
\text { tension } \\
\text { of cable } \\
6 \#\end{array}$ & 4.98 & 3.24 & 3.06 & 1.85 & 2.2 & 3.87 & 2.36 & 3.0 & 1.14 & 2.29 \\
\hline $\begin{array}{c}\text { After } \\
\text { third } \\
\text { tension } \\
\text { of cable } \\
7 \#\end{array}$ & 3.75 & 2.87 & 2.93 & 2.01 & 3.06 & 4.15 & 2.69 & 3.20 & 1.98 & 2.59 \\
\hline $\begin{array}{c}\text { After } \\
\text { third } \\
\text { tension } \\
\text { of cable } \\
8 \#\end{array}$ & 4.64 & 2.46 & 3.26 & 2.14 & 3.27 & 4.98 & 2.93 & 3.52 & 2.19 & 2.80 \\
\hline $\begin{array}{c}\text { After } \\
\text { third } \\
\text { tension } \\
\text { of cable } \\
\text { 9\# }\end{array}$ & 5.83 & 2.52 & 3.64 & 2.26 & 3.43 & 5.76 & 3.11 & 3.81 & 2.37 & 3.09 \\
\hline
\end{tabular}




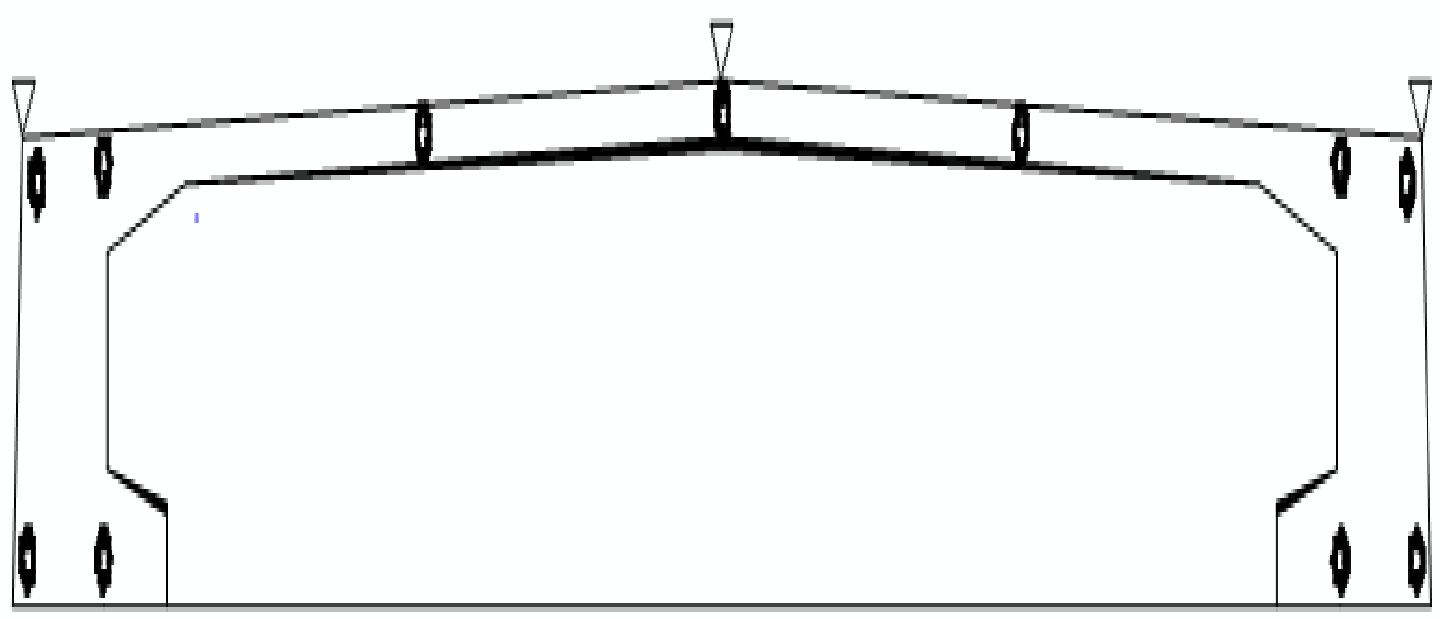

Fig.8 Arrangement of Stress Sensors of the Girder Section

Test stress values of the sensor embedded in the second segment of the girder after the third tensioning are listed in Table 3. It is seen from the data that there is tensile stress in the lower margin of girder after tensioning of segment 2\# because girder segment is too short and rigidity is too large. This kind of tensile stress which is caused by bending moment of the cable force should be within the specified allowable safety value ${ }^{[6]}$. The horizontal cable force and the compressive stress reserve are becoming larger with the elongation of the girder segment, which makes the structure safer. In the middle of the upper section, test value is more than theoretical value, while in the two ends it is different. This is because shear lag effect is ignored in practice ${ }^{[7]}$. It is concluded that the stress is appropriate and satisfied with the requirements of the specification.

The middle test value is the average stress value of the 3 sensors in the middle, ends test value is the average stress value of the two sensors in each end, and lower test value is the average stress value of the 4 sensors in the lower margin.

\section{Stress and Displacement Control of Pylon}

To control the stress and displacement of the pylon supports, following measures are taken after calculation:

1) Two transverse supports are $10 \mathrm{~m}$ away from the top of the upper cross beam based on the original design, with reaction of $1000 \mathrm{kN}$, to strengthen transverse connection of these two pylon supports.

2) Stress sensor should be embedded in the intersection which is on the top upper pylon column and the upper cross beam to monitor the stress safety of the upper pylon column.

During synchronous construction, minimum test compressive stress on the pylon support bottom is $1.13 \mathrm{MPa}$, maximum axial deflection is $8 \mathrm{~mm}$ and the minimum transverse deflection is $6 \mathrm{~mm}$, as shown in Table 4. Pylon support stress and construction accuracy are controlled accordingly ${ }^{[8]}$. 
Tab.4 Test Stress Value on the Pylon Support Bottom and Test Displacement on the Top of the Pylon Support

\begin{tabular}{|c|c|c|c|c|c|c|c|}
\hline $\begin{array}{l}\text { Working } \\
\text { condition }\end{array}$ & $\begin{array}{c}\text { 3\#cable } \\
\text { After } \\
\text { third }\end{array}$ & $\begin{array}{c}\text { 4\#cable } \\
\text { After } \\
\text { third }\end{array}$ & $\begin{array}{c}\text { 5\#cable } \\
\text { After } \\
\text { third }\end{array}$ & $\begin{array}{c}\text { 6\#cable } \\
\text { After } \\
\text { third }\end{array}$ & $\begin{array}{c}\text { 7\#cable } \\
\text { After } \\
\text { third }\end{array}$ & $\begin{array}{c}\text { 8\#cable } \\
\text { After } \\
\text { third }\end{array}$ & $\begin{array}{c}\text { 9\#cable } \\
\text { After } \\
\text { third }\end{array}$ \\
\hline
\end{tabular}

Stress on the upper pylon 1.13 1.28

1.51

1.74

1.89

2.25

2.56 bottom[MPa]

Axial displacement on the top of the pylon

support[mm]

4

6

7

6

8

5

7

Transverse displacement on the top of 2 4 3

4

1

3

6 support [mm] 


\section{Summary}

Synchronous construction method of pylon and girder is not constrained by the general construction $\operatorname{method}^{[9,10]}$; it is concluded as follows through calculation and analysis of the Maling River Bridge: 1) During synchronous construction, girder construction could be controlled in light of the conventional construction control method. After completion, the effect on the cable force, girder alignment and internal force is small.

2) The effect of synchronous construction on the pylon is more significant than the effect on the girder. So measures need to be taken to strengthen the transverse link and overall rigidity of the pylon during synchronous construction and to ensure effective control of the pylon perpendicularity, deflection on the top of the pylon support and the compressive stress of the intersection.

3) During synchronous construction, construction platform is added to shorten the schedule and decrease the construction cost.

\section{Acknowledgement}

This research was financially supported by the National Basic Research Program of China (973 Program) (2015CB057702).

\section{References}

[1] Design Document of Guizhou Maling River Bridge on Shantou to Kunming Expressway [Z]. CCCC Second Highway Consultant Co., Ltd, Wuhan, 2006.

[2] Chen Mingxian. Cable-stayed Bridge Construction Technology [M]. Beijing: China Communications Press, 2003.

[3] Yan Donghuang. A Reasonable Design State and Construction of Cable-Stayed Bridge [D]. Changsha: Hunan University, 2001.

[4] Shao Xudong, Cheng Xiangyun, Li Lifeng. Bridge Design and Computation [M]. Beijing: China Communications Press, 2007.

[5] Gu Anbang, Zhang Yongshui. Bridge Construction Monitoring and Control [M]. Beijing: China Communications Press, 2001.

[6] CCCC Highway Consultants CO., Ltd.JTG D62-2004 Code for Design of Highway Reinforced Concrete and Prestressed Concrete Bridges and Culverts [S]. Beijing: China Communications Press, 2005.

[7] Wu Wenqing, Ye Jianshu, Yang Xiaozhong. Discussions about the Existing Problems of the Theoretical Studies on Shear Lag Effect of Thin-walled Box Girder [J]. Bridge Construction, 2001(1).

[8] Road and Bridge Group First Highway Engineering Co., Ltd. JTJ041-2000 Technical Specification for Construction of Highway Bridge and Culvert [S]. Beijing: China Communications 
Press, 2001.

[9] Zhang Yongjun, Jiang Weidong. Synchronous Construction Plan and Control Technique of the Pylon and Girder of Ultra-wide Cable-Stayed Bridge [J]. Journal of Highway and Transportation Research and Development, 2009(5): 172-175.

[10] Sun Quansheng, Sun Yongcun. Synchronous Construction Plan and Control Technique of the Pylon and Girder of Ultra-wide Cable-Stayed Bridge [J].Highway, 2007(4): 88-91. 